\title{
Pengaruh Model Pembelajaran STAD Dipadu Media Pembelajaran Komik Materi Sistem Pencernaan Manusia terhadap Hasil Belajar Siswa
}

\author{
Siis Werimon ${ }^{1)}$, Insar Damopolii ${ }^{2)}$, Jan H. Nunaki ${ }^{3)}$ \\ ${ }^{1)}$ Jurusan Pendidikan Biologi, FKIP, Universitas Papua \\ i.damopoli@unipa.ac.id
}

\begin{abstract}
This study aims to know the effect of Student Team Achievement Division (STAD) learning model combined comic learning media on student achievement. The type of research was a quasi experimental used the nonequivalent control group design. The study population was all students of class VIII SMP N 15 Manokwari, amounting to 84 students. Determination of sample used purposive sampling technique and obtained class VIII A with a number of 29 students (as experiment class) and class VIII B with a number of 26 students (as control class). Data analysis used Mann Whitney Test at 0.05 significant level with the help of SPSS 22 for windows program. The results showed that the significant value of $0.00<\alpha=0.05$ with the average of student achievement that taught with STAD learning model combined comics of 68.34 higher than in students who were taught by conventional learning model with the average results learning for 54.00. The conclusion, there is an effect of STAD learning model combined with comic learning material of human digestive system on student achievement.
\end{abstract}

Keywords : Learning model, STAD, Comic, Learning media, Student achievement

This is an open access article distributed under the Creative Commons 4.0 Attribution License, which permits unrestricted use, distribution, and reproduction in any medium, provided the original work is properly cited $\odot 2018$ by author and Universitas Negeri Padang.

\section{PENDAHULUAN}

Pembangunan di bidang pendidikan merupakan suatu upaya untuk mewujudkan sumber daya manusia yang menguasai ilmu pengetahuan dan teknologi (IPTEK). Pendidikan diharapkan dapat meningkatkan produktivitas dari manusia, dimana pendidikan tidak terlepas dari kegiatan belajar. Slameto (2013) menyata kan bahwa belajar ialah proses usaha yang dilakukan seseorang untuk memperoleh suatu perubahan tingkahlaku, sebagai hasil pengala mannya sendiri dalam interaksi dengan lingkung an. Pengalaman dan tingkahlaku ini dapat diperoleh secara bertahap dan berkelanjutan yang dimulai dari masa setelah lahir hingga masa manula.

Rendahnya proses pembelajaran yang diperoleh siswa merupakan salah satu masalah yang dihadapi oleh tenaga pendidik. Proses pembelajaran berjalan efektif jika didukung oleh penunjang dalam hal ini model ataupun media yang dapat digunakan sebagai alat bantu serta mempermudah proses pembelajaran. Model pembelajaran berperan sebagai suatu cara untuk menciptakan proses belajar mengajar yang menarik, sehingga tumbuh berbagai kegiatan belajar siswa yang bersifat aktif. Guru dalam proses interaksi belajar mengajar di kelas berperan sebagai pembimbing dan fasilitator, sedangkan siswa bergerak sebagai penerima atau terbim bing. Proses interaksi akan berjalan baik jika peserta didik lebih aktif dibanding guru. Agar siswa mampu menyelesaikan pemahaman materi pelajaran dengan baik sesuai dengan tujuan pembelajaran yang akan dicapai, maka guru harus lebih cermat dalam memilih model pembelajaran yang sesuai dengan karakteristik siswanya, dibantu dengan media pembelajaran yang tepat.

Proses pembelajaran IPA biologi di SMP Negeri 15 Manokwari, berdasarkan hasil observasi dan wawancara dengan guru biologi kelas VIII diperoleh bahwa terdapat beberapa kasus yang dihadapi guru dalam proses pembelajaran. Kasus tersebut adalah peserta didik sulit memahami dan memperhatikan guru mengajar sehingga sulit untuk menjawab soalsoal. Kemudian proses pembelajaran yang dilaksanakan oleh guru kurang dalam meng gunakan media, model atau metode pem belajaran yang tepat namun masih menggunakan metode pembelajaran konvensional.

Penggunaan model pembelajaran dan media pembelajaran yang kurang tepat dapat mempengaruhi perhatian siswa dalam mema hami materi pelajaran yang disampaikan oleh guru. Peserta didik menjadi tidak perhatian 
dengan materi yang disampaikan oleh guru, bermain sendiri dan bercerita dengan temannya. Gaya mengajar guru cenderung bersifat otoriter dan instruktif, dan proses komunikasinya terjadi hanya satu arah. Guru memegang kendali, memainkan peran aktif sementara siswa menerima secara pasif informasi keterampilan dan pengetahuan. Hal ini sangat bertentangan dengan prinsip pembelajaran berpusat pada siswa yaitu siswa yang menjadi pusat pembelajaran atau peserta didik lebih aktif dalam memperoleh pengetahuan. Guru kurang memberi kesempatan pada peserta didik sehingga cenderung menjadi pasif. Akhirnya membuat kreatifitas dan sifat mandiri peserta didik tidak dapat berkembang dengan baik. Realita inilah yang sangat tidak diinginkan terjadi dalam proses pembelajaran khususnya IPA biologi karena ini akan berdampak pada pemahaman siswa dan ketercapaian tujuan pembelajaran serta akhirnya berdampak pada hasil belajar siswa yang rendah.

Salah satu cara yang dilakukan untuk mengatasi kasus tersebut adalah dengan menggunakan model pembelajaran berpusat pada siswa yang dibantu dengan media pembelajaran. Menurut Komalasari (2013) bahwa pembelajaran dipandang sebagai suatu sistem, terdiri dari sejumlah komponen yang terorganisasi antara lain tujuan pembelajaran, materi pembelajaran, strategi dan metode pembelajaran, media pembelajaran/alat peraga, pengorganisasian kelas, evaluasi pembelajaran dan tidak lanjut pembelajaran. Berdasarkan pendapat ini dapat dikatakan bahwa dalam proses pembelajaran dibutuhkan beberapa model dan alat bantu untuk menunjang suksesnya pembelajaran. Salah satu model pembelajaran yang paling sederhana untuk dilaksanakan dalam proses pembelajaran adalah model pembelajaran Student Team Achievement Division (STAD).

Hasil penelitian dari Tiantong dan Teemuangsai (2013) dan Saputra dkk (2017), menunjukkan bahwa model pembelajaran STAD memiliki pengaruh terhadap peningkatan hasil hasil belajar siswa. Penelitian Mariana dkk (2014) menunjukkan bahwa pemahaman isi bacaan berbasis teks cerita bahasa Indonesia siswa yang dibelajarkan dengan model pembelajaran kooperatif tipe student team achievement division (STAD) lebih baik daripada prestasi pemahaman isi bacaan berbasis teks cerita bahasa Indonesia siswa yang mengikuti model pembelajaran konvensional. Hal ini menunjukkan bahwa STAD mempunyai pengaruh terhadap hasil belajar dan pemahaman isi bacaan. Namun penelitian Khan (2011) menyimpulkan bahwa tidak ada perbedaan signifikan antara hasil belajar siswa kelas eskperimen yang dibelajarkan dengan model pembelajaran kooperatif tipe STAD dan hasil belajar siswa kelas kontrol. Untuk mengatasi hal tersebut, dibutuhkan suatu alat bantu untuk mengantarkan pesan atau materi kepada siswa. Salah satu alat bantu untuk mengantarkan pesan adalah media pembelajaran. Penggunaan media pendidikan secara tepat dan bervariasi dapat mengatasi sikap pasif siswa dalam proses belajar mengajar.

Media merupakan alat bantu yang digunakan guru untuk mentransfer informasi kepada siswanya. Media memiliki fungsi dalam penggunaanya pada proses belajar mengajar. Menurut Iriantara (2014) bahwa fungsi media dalam proses belajar mengajar untuk menarik perhatian siswa, membantu untuk mempercepat pemahaman, membantu penyajian pesan agar tidak verbalis, mengatasi keterbatasan ruang, penjelasan lebih komunikatif dan produktif, waktu pembelajaran dapat dikondisikan, meng hilangkan rasa kebosanan, meningkatkan moti vasi dan keaktifan siswa.

Menurut Arsyad (2014) beberapa manfaat praktis dari penggunaan media pembelajaran di dalam proses pembelajaran seperti dapat memperjelas penyajian pesan dan informasi sehingga dapat memperlancar dan meningkatkan proses dan hasil belajar, dapat meningkatkan dan mengarahkan perhatian anak sehingga dapat menimbulkan motivasi belajar, interaksi yang lebih langsung antara siswa dan lingkungannya, dan kemungkinan siswa untuk belajar sendirisendiri sesuai dengan kemampuan dan minat nya, dapat mengatasi keterbatasan indra, ruang dan waktu, dapat memberikan kesamaan pengalaman kepada siswa tentang peristiwaperistiwa di lingkungan mereka sendiri, serta memungkinkan terjadinya interaksi langsung dengan guru, masyarakat, dan lingkungannya

Pembelajaran tidak selamanya harus mengajak siswa ke dalam situasi yang nyata, tetapi bisa mengajak siswa ke dalam sesuatu yang abstrak. Untuk membantu siswa dalam memahami materi yang abstrak maka dibutuh kan suatu media pembelajaran. Menurut Iriantara (2014) bahwa media memiliki andil untuk menjelaskan hal-hal yang abstrak dan 
menunjukkan hal-hal yang tersembunyi. Maka seorang guru dapat memanfaatkan media dalam pembelajaran agar terciptanya pembelajaran yang aktif, menghilangkan kebosanan siswa, fokusnya siswa terhadap materi pembelajaran yang sedang diajarkan guru dan siswa akan menjadi lebih mengerti materi yang diajarkan guru secara verbalis. Banyak media yang dapat digunakan oleh seorang guru dalam proses belajar mengajar, salah satunya media grafis berupa komik pembelajaran yang dapat membuat siswa menjadi tertarik untuk membaca materi pelajaran yang termuat dalam komik pembelajaran.

Mahmudah (2014) menyatakan bahwa komik adalah cerita dalam bentuk kartun yang mengungkapkan karakter dan dan memerankan suatu rentetan cerita yang dibuat dan dilengkapi dengan balon-balon kata yang bersifat lucu dan menghibur, biasanya terdapat dalam majalah, surat kabar atau dibuat dalam bentuk buku. Komik sebagai wadah pembelajaran bagi anakanak yang dikemas sangat menarik minat pembaca. Menurut Daryanto (2016) bahwa peserta didik cenderung tidak menyukai buku teks apalagi yang tidak disertai gambar dan ilustrasi yang menarik, dan secara empirik siswa cenderung menyukai buku bergambar, penuh dengan warna, dan divisualisasikan dalam bentuk realistis atau kartun

Penyusunan media pembelajaran komik harus memperhatikan bentuk, warna, karakter dari tokoh yang ada dalam komik narasi atau jalan cerita dari materi sistem pencernaan manusia. Jalan cerita materi sistem pencernaan akan menceritakan bagaimana suatu makanan diproses di dalam tubuh manusia, dimana seorang akan memakan sebuah makanan dan akan menjelaskan kepada temannya proses yang terjadi ketika makanan masuk dalam tubuh. Karakter tokoh dalam komik menggunakan karakter masyarakat papua tetapi penggunaan bahasa menggunakan bahasa Indonesia. Karakter ditampilkan dalam bentuk kartun. Menurut Koasih (2014) bahwa kartun merupakan suatu gambar interpretatif yang menggunakan simbol-simbol untuk menyam paikan suatu pesan secara cepat dan ringkas atau sikap terhadap orang, situasi, atau kejadiankejadian tertentu. Dengan menampilkan karakter dalam bentuk kartun maka materi yang akan diajarkan akan mudah dipahami oleh siswa.

Media komik memiliki fungsi yaitu sebagai media yang menghibur, dan meng edukasi para pembaca. Peran komik dalam edukasi dapat ditemukan seperti dalam buku pelajaran yang menggunakan komik sebagai salah satu materi dalam pemberian informasi. Penggunaan gambar pada buku pelajaran mampu untuk menyalurkan informasi yang mudah untuk dipahami walaupun ditampilkan dalam gambar sederhana. Damopolii dan Nunaki (2016) mengatakan bahwa Media komik IPA materi sistem pencernaan manusia dapat berfungsi sebagai media pembelajaran mandiri karena siswa dapat menemukan sendiri konsep IPA yang dimaksud dengan atau tanpa bantuan dari guru.

\section{METODE PENELITIAN}

Penelitian dilaksanakan di kelas VIII SMP Negeri 15 Manokwari pada Semester ganjil tahun pelajaran 2016/2017. Jenis penelitian yang dapat digunakan yaitu quasi eksperimen dengan menggunakan non equiva lent control group design. Kuasi eksperimen bertujuan untuk memprediksi keadaan yang dapat dicapai melalui pengujian variabel independen dan variabel dependen pada kelas eksperimen dan kelas kontrol, khususnya pada kelas kontrol tidak sepenuhnya untuk mengontrol variabel-variabel luar yang mem pengaruhi pelaksanaan eksperimen.

Tabel 1. Nonequivalent Control Group Design

\begin{tabular}{|c|c|c|}
\hline Pre-test & Perlakuan & Post-test \\
\hline $\mathrm{O}_{1}$ & $\mathrm{X}$ & $\mathrm{O}_{2}$ \\
\hline $\mathrm{O}_{3}$ & & $\mathrm{O}_{4}$ \\
\hline
\end{tabular}

Sugiyono, (2015)

Keterangan:

$\mathrm{O}_{1}=$ Pre-test kelas eksperimen

$\mathrm{O}_{2}=$ Post-test kelas eksperimen

$\mathrm{O}_{3}=$ Pre-test kelas kontrol

$\mathrm{O}_{4}=$ Post-test kelas kontrol

$\mathrm{X}=$ Perlakuan dengan penerapan model pem belajaran STAD berbantuan komik

Populasi dalam penelitian yaitu seluruh siswa kelas VIII SMP Negeri 15 Manokwari Semester ganjil, yang terdiri dari 3 kelas dengan jumlah siswa 84 orang. Sampel dalam penelitian ditentukan dengan tenik purposive sampling, yaitu pengambilan subyek bukan berdasarkan strata dan random tetapi atas tujuan tertentu. Sampel yang diambil berasal dari kelas VIIIA 
sebanyak 29 siswa sebagai kelas eksperimen dan kelas VIIIB sebanyak 26 siswa sebagai kelas kontrol.

Perangkat pembelajaran yang digunakan dalam penelitian ini adalah silabus, rencana pelaksanaan pembelajaran (RPP) yang terdiri dari RPP untuk kelas eksperimen dan RPP untuk kelas kontrol, soal tes untuk pre-test dan posttest, lembar observasi untuk kegiatan guru, lembar observasi kegiatan siswa, lembar kerja siswa (LKS), media pembelajaran komik materi sistem pencernaan pada manusia. Perangkat ini sebelum digunakan terlebuh dahulu di validasi oleh validator. Keseluruhan perangkat yang digunakan dalam penelitian merupakan pene litian hasil penelitian dan pengembangan Damopolii dan Nunaki (2016) yang keseluruhan perangkat telah divalidasi oleh ahli materi, ahli media dan praktisi.

Uji normalitas dilakukan untuk menguji data yang digunakan berdistribusi normal atau tidak. Normalitas yang digunakan dalam penelitian ini adalah uji Kolmogorov-Smirnov dengan $\alpha=0,05$. Uji hipotesis dalam penelitian ini menggunakan Uji Mann Whitney, analisis data menggunakan bantuan softwere SPSS 22.

\section{HASIL DAN PEMBAHASAN}

Data rata-rata hasil pre-test siswa kelas eksperimen dan kontrol dilakukan uji perbedaan hasil belajar. Sebelum dilakukan uji perbedaan nilai rata-rata terlebih dahulu uji normalitas. Uji normalitas menggunakan uji Kolmogorov Smirnov (Tabel 2).

Tabel 2. Data Hasil Uji Normalitas Pre-test Kelas Eksperimen dan Kontrol

\begin{tabular}{|l|l|c|c|c|c|}
\hline No & Kelompok & df & Sig. & $\alpha$ & Ket \\
\hline 1 & Eksperimen & 29 & 0,00 & 0,05 & $\begin{array}{c}\text { Tidak } \\
\text { normal }\end{array}$ \\
\hline 2 & Kontrol & 26 & 0,00 & 0,05 & $\begin{array}{c}\text { Tidak } \\
\text { normal }\end{array}$ \\
\hline
\end{tabular}

Berdasarkan Tabel 2 menunjukkan bahwa nilai signifigkan kelas eksperimen 0,00 dan nilai signifikan kelas kontrol 0,00 data tersebut lebih kecil dari taraf signifikan 0,05. Hasil ini menunjukkan bahwa data kelas eksperimen dan kelas kontrol tidak berdistribusi normal. Setelah data diketahui tidak normal maka tidak dilanjutkan pada uji homogenitas. Untuk uji perbedaan menggunakan analisis non parametrik yaitu uji Mann Whitney untuk mengetahui perbedaan pre-test kelas eksperimen dan kelas kontrol.

Tabel 3. Data Hasil Uji Mann Whitney Perbedan Pre-test Kelas Eksperimen dan Kelas Kontrol

\begin{tabular}{|c|c|c|c|c|}
\hline Kelompok & $\begin{array}{c}\text { Rata- } \\
\text { rata }\end{array}$ & Sig. & $\alpha$ & Ket \\
\hline Eksperimen & 22,52 & 0,233 & 0,05 & $\begin{array}{l}\text { Tidak ada } \\
\text { perbedaan }\end{array}$ \\
\hline Kontrol & 26,42 & & &
\end{tabular}

Pada Tabel 3 uji perbedaan hasil pre-test kelas eksperimen dan kelas kontrol dengan menggunakan uji Mann Whitney terlihat bahwa diperoleh nilai sig. 0,233. Data nilai signifikan lebih besar dari $\alpha=(0,05)$ sehingga dinyatakan bahwa $\mathrm{H}_{0}$ diterima. Artinya tidak terdapat perbedaan pre-test pada kedua kelas yakni kelas eksperimen dan kelas kontrol. Hasil ini menunjukkan bahwa kemampuan awal siswa pada kelas eksperimen dan kelas kontrol adalah sama.

Visualisasi dari perbedaan rata-rata skor Pre-test adalah sebagai berikut:

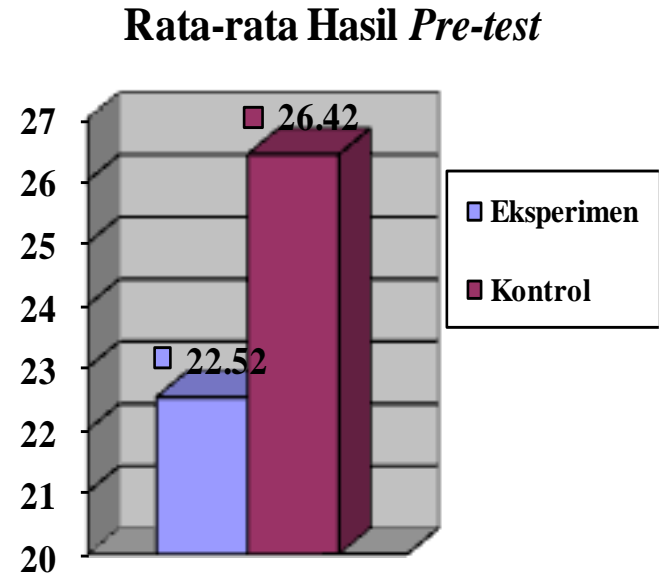

Gambar 1. Grafik Perbedaan Rata-rata Hasil Pre-test

Pada awalnya sebelum melaksanakan proses pembelajaran, siswa diberikan pre-test dengan tujuan mengetahui kemampuan kognitif siswa antara kelas eksperimen dan kelas kontrol. Berdasarkan data dari 29 siswa kelas eksperimen diperoleh nilai rata-rata pre-test 22,52 sementara nilai rata-rata pre-test kelas kontrol 26,42 dengan jumlah siswa adalah 26 orang. Data hasil analisis Mann Whitney menunjukkan bahwa kemampuan awal pada siswa kelas eksperimen dan kelas kontrol memiliki kesamaan nilai dengan kategori rendah. Namun berdasarkan nilai rata-rata bahwa siswa kelas kontrol memiliki kemampuan awal lebih tinggi daripada siswa pada kelas 
eksperimen. Rendahnya nilai pre-test kedua kelompok ini disebabkan oleh materi yang diujikan belum diajarkan kepada siswa sehingga mereka menjawab soal tes sesuai dengan pemahamannya sendiri. Kemampuan awal merupakan kemampuan siswa sebelum dilak sanakannya proses pembelajaran. Dalam peneliti an eksperimen, kemampuan awal siswa harus sama, tetapi jika berbeda maka analisis dilanjutkan dengan analisis gain. Karena tidak ada perbedaan maka tidak dilanjutkan dengan analisis gain.

Tabel 4. Data Hasil Uji Normalitas Post-test Kelas Eksperimen dan Kontrol

\begin{tabular}{|c|l|c|c|c|c|}
\hline No & Kelompok & df & Sig. & $\alpha$ & Ket \\
\hline 1 & Eksperimen & 29 & 0,005 & 0,05 & $\begin{array}{c}\text { Tidak } \\
\text { normal }\end{array}$ \\
\hline 2 & Kontrol & 26 & 0,019 & 0,05 & $\begin{array}{c}\text { Tidak } \\
\text { normal }\end{array}$ \\
\hline
\end{tabular}

Pada Tabel 4 terlihat bahwa data nilai signifikan pada kelas post-test eksperimen 0,005 dimana < $(0,05)$, dan post-test kelas kontrol nilai signifikan 0,019 dimana $<(0,05)$ sehingga data post-test kelas kontrol berasal dari populasi tidak berdistribusi normal. Ini menunjukkan hasil uji normalitas belum menunjukkan hasil yang berdistribusi normal, maka uji parametrik tidak dapat dilakukan.

Berdasarkan hasil uji normalitas terhadap data post-test kelas eksperimen dan kelas kontrol dengan dilanjutkan dengan analisis non parametrik menggunakan uji Mann Whitney dengan $\alpha=(0,05)$.

Tabel 5. Data Hasil Uji Mann Whitney Perbeda an Post-test Kelas Eksperimen dan Kelas Kontrol

\begin{tabular}{|c|c|c|c|c|}
\hline Kelompok & $\begin{array}{c}\text { Rata- } \\
\text { rata }\end{array}$ & Sig. & $\alpha$ & Ket \\
\hline Eksperimen & 68,35 & 0,00 & 0,05 & $\begin{array}{l}\text { Terdapat } \\
\text { perbedaan }\end{array}$ \\
\hline Kontrol & 54,00 & & & \\
\hline
\end{tabular}

Berdasarkan data pada Tabel 5 diperoleh signifikan untuk Post-test kelas ekperimen dan kelas kontrol yaitu $0,00<0,05$ maka dinyatakan terdapat perbedaan rata-rata nilai post-test kelas eksperimen dan kelas kontrol. Dengan demikian menunjukkan bahwa, $\mathrm{H}_{0}$ ditolak dan $\mathrm{H}_{1}$ diterima dalam arti bahwa terdapat perbedaan hasil belajar siswa kelas eksperimen dan kelas kontrol.

Visualisasi dari perbedaan rata-rata skor post-test adalah sebagai berikut:

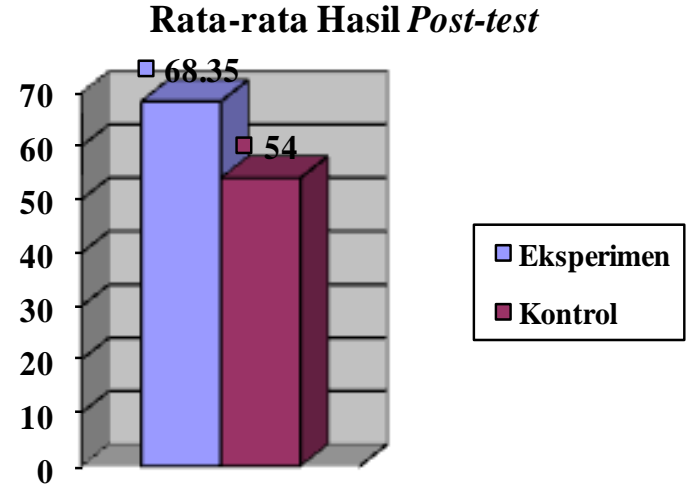

Gambar 2. Grafik Perbedaan Rata-Rata Hasil Post-test

Data hasil penelitian menunjukkan bahwa post-test kelas eksperimen dan kelas kontrol berbeda nyata. Peningkatan hasil belajar kelas eksperimen menggunakan model pembelajaran STAD berbantuan komik lebih tinggi dibanding kan dengan kelas kontrol, hal ini disebabkan pada kelas kontrol masih menggunakan pembelajaran konvensional. Dengan demikian dapat dikatakan bahwa dengan menerapkan model pembelajaran STAD berbantuan komik efektif digunakan karena meningkatkan hasil belajar siswa. Damopolii dan Nunaki (2016) menyimpulkan bahwa media pembelajaran komik efektif dalam meningkatkan hasil belajar siswa. Media komik dapat berpengaruh terhadap peningkatan hasil belajar. Kesimpulan ini didukung oleh Rahmawati, dkk (2015) pening katan hasil belajar merupakan bukti nyata bahwa penggunaan bahan ajar yang berbeda berpe ngaruh terhadap hasil belajar siswa.

Menurut Damopolii (2017) bahwa pembelajaran yang kreatif dan inovatif adalah proses belajar mengajar yang terbarukan dalam memadukan media pembelajaran komik dengan model pembelajaran yang sering dilaksanakan dalam proses belajar mengajar. Pembelajaran dengan menggunakan media komik memberikan pengaruh yang positif bagi siswa, dimana pesan yang disampaikan dalam bahan ajar sistem pencernaan manusia lebih mudah diingat karena berbentuk ilustrasi yang menarik perhatian siswa.

Model pembelajaran kooperatif tipe STAD merupakan model yang paling sederhana, dimana dituntut untuk kerja sama, siswa lebih mudah memahami materi tersebut karena belajar bersama teman sebaya dan dibawa bimbingan 
guru, maka proses penerimaan dan pemahaman siswa semakin mudah dan cepat terhadap materi yang dipelajari. Menurut Shoimin (2014), bahwa gagasan utama model pembelajaran Student Teams Achievement Division (STAD) adalah untuk memotivasi para siswa, mendorong dan membantu satu sama lain, dan untuk menguasai ketrampilan-ketrampilan yang disajikan oleh guru. Penerapan model STAD dalam penelitian ini dibantu oleh media komik untuk menunjang proses pembelajaran dan mempermudah pema haman siswa terhadap pokok materi sistem pencernaan manusia. Menurut Damopolii (2017) bahwa komik merupakan media pembelajaran yang membantu siswa memahami konsep suatu materi. Pokok materi yang disajikan dalam isi komik yaitu sistem pencernaan manusia yang disusun berbentuk cerita bergambar.

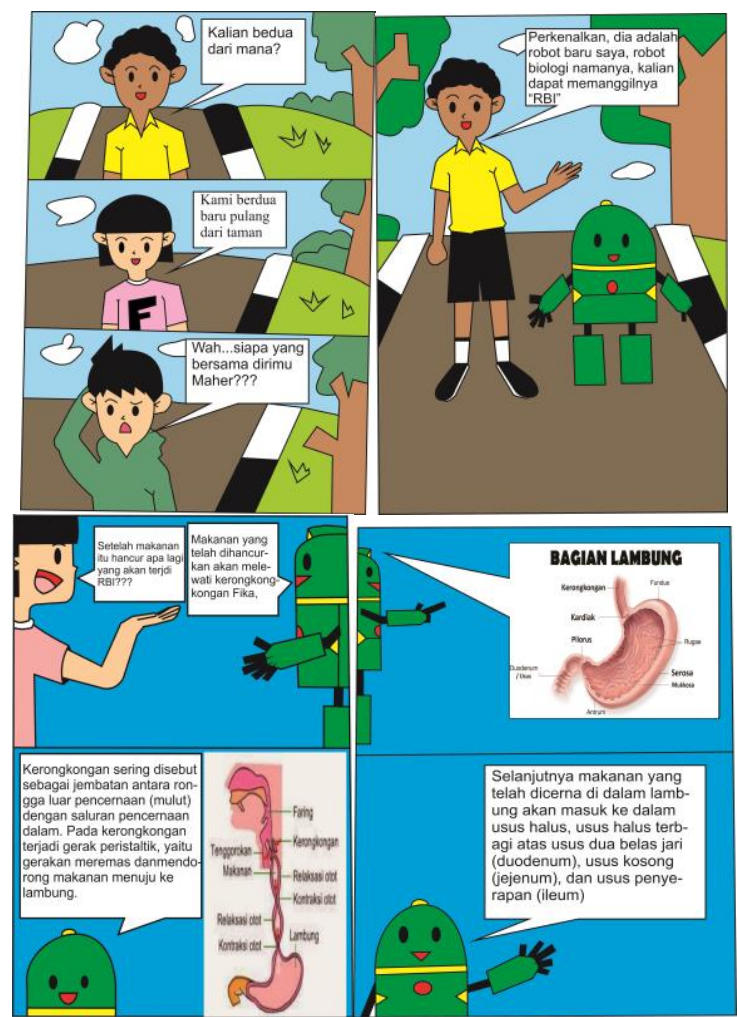

Gambar 3. Media Pembelajaran Komik Sistem Pencernaan pada Manusia

Media Komik adalah sebuah rangkaian cerita bergambar yang dilengkapi tulisan sederhana yang memperjelas sajian gambar. Selain itu, dengan adanya bantuan media komik dapat berfungsi sebagai media pendeskripsian cerita, sehingga pembaca bukan sekedar membayangkan karakter toko dan lokasi yang menjadi latar belakang cerita tersebut, tetapi juga dapat sebagai penyampai pesan atau informasi dari penulis atau ilustrator terhadap pembaca yang dapat digunakan atau dinikmati oleh semua orang dengan strata usia yang beragam. Menurut Babaian dan Chalian (2014) bahwa buku komik adalah bentuk grafis dan seni rupa dan secara fundamental merupakan narasi visual yang menciptakan dunia maya yang dapat menceritakan sebuah cerita, menggambarkan prosedur, mengajarkan sebuah teori, menyajikan sebuah hipotesis, menjawab pertanyaan, dan melibatkan pembaca.

Ilustrasi yang terdapat dalam media komik materi sistem pencernaan pada manusia membantu siswa untuk memahami materi yang sulit dengan cara yang menyenangkan dan merangsang motivasi serta ketertarikan terhadap topik materi pembelajaran yang dianggap sulit untuk dimengerti, merangsang aktivitas diskusi, membangun pemahaman dan memperpanjang daya ingat, hal ini sependapat dengan Damopolii (2017) yang menyatakan bahwa salah satu media pembelajaran yang membuat siswa menjadi lebih termotivasi adalah komik dan Daryanto (2016) menyatakan bahwa komik menyediakan cerita yang sederhana, mudah ditangkap dan dipahami isinya sehingga sangat digemari oleh anak-anak ataupun orang dewasa

Menurut Lin dkk (2004) bahwa media pembelajaran komik menghadirkan fitur humor, narasi, dan representasi visual yang berpotensi sebagai media pembelajaran untuk menyam paikan informasi sains. Pada media pem belajaran yang digunakan pada kelas eksperimen terdapat gambar dan kotak yang berisi informasi sains mengenai sistem pencernaan pada manusia. Hal sesuai dengan pendapat dari Spiegel dkk (2013) bahwa komik menghadirkan fitur gambar yang di dalamnya mengandung karakter dan dialog yang disampaikan melalui gelembung. Dalam penelitian ini gelembung berbentuk segi empat.

Damopolii dkk (2017) menyatakan bahwa dengan adanya motivasi, seorang siswa akan melakukan apa saja untuk mencapai tujuannya yaitu memperoleh hasil belajar yang baik. Model pembelajaran STAD yang dipadu media pembelajaran komik membuat siswa termotivasi untuk belajar karena ilustrasi gambar yang menarik. Menurut Sadiman (2012) bahwa siswa cenderung pasif dalam kegiatan pembelajaran apabila sarana prasarana belajar kurang men dukung. Adanya dukungan media pembelajaran komik sistem pencernaan pada manusia men dukung proses pembelajaran berbasis STAD. 
Karakter animasi yang ditampilkan berupa RBI merupakan robot biologi yang pintar dengan karakteristik disesuaikan dengan kondisi siswa SMP. Pembelajaran dengan model STAD yang terbilang sederhana menjadi lebih baik dengan adanya media pembelajaran komik.

Hasil penelitian yang diperoleh sejalan dengan hasil penelitian Damopolii (2017) yang menyimpulkan bahwa siswa yang dibelajarkan dengan menggunakan model pembelajaran kooperatif tipe STAD berbantuan media pem belajaran komik IPA terpadu lebih tinggi peningkatan hasil belajarnya dibandingkan dengan hasil belajar siswa yang dibelajarkan dengan menggunakan model kooperatif tipe STAD tanpa menggunakan komik. Hasil pretest menunjukkan bahwa rata-rata kelas kontrol lebih tinggi dibandingkan dengan kelas eksperimen. Setelah siswa mengalami pem belajaran, hasil belajar belajar siswa pada kelas eksperimen yaitu siswa yang dibelajarkan dengan model pembelajaran STAD dipadu media pembelajaran komik lebih tinggi dibandingkan siswa pada kelas kontrol yaitu siswa yang dibelajarkan dengan model konvensional. Perpaduan antara model pem belajaran STAD dan komik mebuat siswa lebih aktif dalam proses pembelajaran.

Model pembelajaran STAD yang seder hana membuat guru dapat menjalankan pem belajaran dengan baik dibantu dengan media pembelajaran komik yang membuat siswa tertarik membaca materi dan konsep materi pembelajaran dapat bertahan lama. Hasil penelitian Aleixo dan Sumner (2016) menun jukkan bahwa skor memori secara signifikan lebih tinggi dibandingkan dengan kondisi pembelajaran yang hanya menggunakan teks dan pembelajaran tanpa menggunakan komik. Bertahan lamanya hasil belajar siswa dibuktikan dengan hasil post-test yang lebih baik pada kelas eksperimen.

Media pembelajaran komik yang diguna kan pada kelas eksperimen membuat siswa menjadi lebih senang belajar dibandingkan dengan buku siswa yang digunakan pada kelas kontrol. Buku siswa yang digunakan pada kelas kontrol yaitu buku yang telah disediakan oleh pihak sekolah, dimana isi buku seperti buku pelajaran lainnya, tetapi gambar yang ditampilkan membuat siswa bosan untuk membacanya. Menurut MERC dan Kampusu (2013) bahwa pengaruh komik terhadap minat baca siswa lebih baik dibandingkan dengan siswa yang belajar tanpa menggunakan komik. Minat membaca yang tinggi membuat siswa lebih memahami isi komik. Pemahaman terha dap isi komik mebuat hasil belajar siswa menjadi lebih baik.

\section{KESIMPULAN}

Kesimpulan dalam penelitian ini adalah bahwa model pembelajaran Student Teams Achievement Division (STAD) berbantuan media pembelajaran komik dapat berpengaruh terhadap hasil belajar materi sistem pencernaan manusia dibandingkan dengan model pem belajaran konvensional. Hasil belajar siswa menjadi lebih baik ketika dibelajarkan dengan media pembelajaran komik. Model pem belajaran STAD dan media pembelajaran komik merupakan perpaduan pembelajaran yang inovatif dan kreatif. Model pembelajaran STAD yang dipadu dengan media pembelajaran komik dapat digunakan oleh guru dalam kegiatan belajar mengajar di dalam kelas untuk memperbaiki kesulitan belajar siswa, sehingga hasil belajar siswa menjadi lebih baik.

\section{DAFTAR PUSTAKA}

Aleixo, P. A. and Sumner, K. 2016. Memory for Biopsychology Material Presented In Comic Book Format. Journal of Gra phic Novels and Comics, 8(1). 79-8

Arsyad, A. 2014. Media Pembelajaran (Edisi Revisi). Jakarta: PT. Raja Grafindo Persada

Babaian, C. S and Chalian, A. A. 2014. The Thyroidectomy Story": Comic Books, Graphic Novels, and the Novel Approach to Teaching Head and Neck Surgery Through the Genre of the Comic Book. Journal of Surgical Education. 71(3). $413-418$

Damopolii, I. 2017. Pengaruh Model Pembelajar an Kooperatif Tipe STAD Berbantuan Media Pembelajaran Komik IPA Terpadu terhadap Peningkatan Hasil Belajar Siswa. Prosiding Simpo sium Nasional MIPA (hal. 134-137). Makassar: Fakultas MIPA Universitas Negeri Makassar. (online) tersedia di: http://mipa. unm.ac.id /mipaopen/ Insar_Damopolii_2017_08_05_09_00_ 17_618.pdf

Damopolii, I., \& Nunaki, J. H. 2016. Pengembangan Media Pembelajaran 
Komik IPA Terpadu Materi Sistem Pencernaan Pada Manusia. Pancaran Pendidikan, 5(3), 61-70.

Damopolii, I., Lefaan, P. Th. dan Manga', M. 2017. Hubungan Motivasi Belajar dengan Hasil Belajar Biologi Siswa Di SMP 21 Rendani Manokwari. Disam paikan dalam Seminar Nasional dan Kongres Himpunan Pendidik dan Peneliti Biologi Indonesia (HPPBI). Mataram 30 September - 1 Oktober 2017. (online) tersedia di: https://www. researchgate.net/publication/321298963

Daryanto. 2016. Media Pembelajaran Edisi Ke 2 Revisi. Yogyakarta: Gava Media

Iriantara, Y. 2014. Komunikasi Pembelajaran, Interaksi Komunikasi dan Edukatif Di Dalam Kelas. Bandung: PT Remaja Rosdakarya.

Khan, G. N. 2011. Effect of Student's Team Achievement Division (STAD) on Academic Achievement of Students. Asian Social Science, 7(12). 211-215

Koasih, E. 2014. Strategi Belajar dan Pembelajaran Implementasi Kurikulum 2013, Bandung: Penerbit Yrama Widya.

Komalasari. K. 2013. Pembelajaran Konteks tual. Bandung: Refika Aditama.

Lin, S. -F., Lin, H. S., Lee, L., \& Yore, L. D. (2014). Are Science Comics a Good Medium for Science Communication? The Case for Public Learning of Nanotechnology. International Journal of Science Education, 276-294.

Mariana, K., Putrayasa, I. dan Suandi, N. 2014. Pengaruh Model Pembelajaran Koopera tif Tipe STAD terhadap Pemahaman Isi Bacaan Berbasis Teks Cerita Bahasa Indonesia dengan Mempertimbangkan Motivasi Berprestasi pada Kelas X SMKN 1 Klungkung Tahun Pelajaran 2014/2015. Jurnal Pendidikan Bahasa, $3(1)$.

Mahmudah, L. 2014. Efektivitas Penggunaan Media Komik Terhadap Pencapaian Kompetensi Pembelajaran SKI Di SMP
Negeri 264 Jakarta. Skripsi. UIN Jakarta. [Online] http://repository.uinjkt. ac.id/

MERÇ, A., \& Kampusu, Y. (2013). The Effect of Comic Strips on EFL Reading Comprehension. International Journal on New Trends in Education and Their Implications, 4(1), 54 - 64.

Rahmawati., Rahmatan, H., dan Hasanudin. 2015. Penerapan Bahan ajar Media Komik pada Konsep Fotosintesis untuk Meningkatkan Hasil Belajar Peserta Didik Di SMP Islam Darul Ulum Banda Aceh. Jurnal EduBio Tropika. 3(1). 33 36

Sadiman, S.A, dkk, 2012. Media Pendidikan (Pengertian, Pengembangan, Peman faatannya). Jakarta: PT Raja Grafindo Persada

Saputra, I. W. R., Rai, I. W. dan Lesmana, K.Y.P., 2017. Pengaruh Penerapan Model Pembelajaran Kooperatif Tipe Student Teams Achievement Division (STAD) Terhadap Hasil Belajar Teknik Dasar Passing Bawah Bola Voli Pada Siswa Kelas VII SMP Laboratorim Undiksha Singaraja Tahun Pelajaran 2016/ 2017. Jurnal Pendidikan Jasmani, Olah raga dan Kesehatan, 8(2).

Slameto. 2013. Belajar dan Faktor-Faktor yang Mempengaruhi. Jakarta: Rineka Cipta

Spiegel, N. A., McQuillan, J., Halpin, P., Matuk, C., \& Diamond, J. (2013). Engaging Teenagers with Science Through Comics. Research in Science Education, 43(6), 2309-2326.

Sugiyono. 2015. Metode Penelitian Kualitatif Kuantitatif dan R\&D. Bandung: Alfabeta

Tiantong, M. and Teemuangsai, S., 2013. Student Team Achievement Divisions (STAD) Technique Through The Moodle to Enhance Learning Achieve ment. International Education Studies, 6 (4), $85-92$ 